\title{
Protein Digestion
}

National Cancer Institute

\section{Source}

National Cancer Institute. Protein Digestion. NCI Thesaurus. Code C70845.

A technique for proteolysis of proteins into peptides by treatment with any of various enzymes. 